\title{
Overview of worldwide diversity of Diaphorina citri Kuwayama mitochondrial cytochrome oxidase 1 haplotypes: two Old World lineages and a New World invasion
}

\author{
L.M. Boykin ${ }^{1, *}{ }^{\dagger}$, P. De Barro ${ }^{2}$, D.G. Hall ${ }^{1}$, W.B. Hunter ${ }^{1}$, \\ C.L. McKenzie ${ }^{1}$, C.A. Powell ${ }^{3}$ and R.G. Shatters, Jr $^{1}$ \\ ${ }^{1}$ USDA, ARS, Horticultural Research Laboratory, 2001 South Rock Road, Fort \\ Pierce, FL 34945, USA: ${ }^{2}$ CSIRO Ecosystem Sciences, GPO Box 2583, Brisbane \\ QLD 4001, Australia: ${ }^{3}$ University of Florida, Indian River Research and \\ Education Center, Fort Pierce, FL 34945, USA
}

\begin{abstract}
Relationships among worldwide collections of Diaphorina citri (Asian citrus psyllid) were analyzed using mitochondrial cytochrome oxidase I (mtCOI) haplotypes from novel primers. Sequences were produced from PCR amplicons of an $821 \mathrm{bp}$ portion of the mtCOI gene using $D$. citri specific primers, derived from an existing EST library. An alignment was constructed using $612 \mathrm{bps}$ of this fragment and consisted of 212 individuals from 52 collections representing 15 countries. There were a total of eight polymorphic sites that separated the sequences into eight different haplotypes (Dcit-1 through Dcit-8). Phylogenetic network analysis using the statistical parsimony software, TCS, suggests two major haplotype groups with preliminary geographic bias between southwestern Asia (SWA) and southeastern Asia (SEA). The recent (within the last 15 to 25 years) invasion into the New World originated from only the SWA group in the northern hemisphere (USA and Mexico) and from both the SEA and SWA groups in the southern hemisphere (Brazil). In only one case, Reunion Island, did haplotypes from both the SEA and SWA group appear in the same location. In Brazil, both groups were present, but in separate locations. The Dcit-1 SWA haplotype was the most frequently encountered, including 50\% of the countries sampled and $87 \%$ of the total sequences obtained from India, Pakistan and Saudi Arabia. The second most frequently encountered haplotype, Dcit-2, the basis of the SEA group, represented $\sim 50 \%$ of the countries and contained most of the sequences from Southeast Asia and China. Interestingly, only the Caribbean collections (Puerto Rico and Guadeloupe) represented a unique haplotype not found in other countries, indicating no relationship between the USA (Florida) and Caribbean introductions. There is no evidence for cryptic speciation for $D$. citri based on the COI region included in this study.
\end{abstract}

Keywords: genetic structure, statistical parsimony, Asian citrus psyllid, citrus, citrus greening disease, Huanglongbing, novel COI primers

(Accepted 29 February 2012; First published online 17 April 2012)

*Author for correspondence

Fax: 6433253864

E-mail: lboykin@mac.com

tCurrent address: Bio-Protection Research Centre, PO Box 84, Lincoln University, Lincoln 7647, Christchurch, New Zealand

The online version of this article is published within an Open Access environment subject to the conditions of the Creative Commons

Attribution-NonCommercial-ShareAlike licence $<$ http://creativecommons.org/licenses/by-nc-sa/2.5/ $>$. The written permission of

Cambridge University Press must be obtained for commercial re-use. 


\section{Introduction}

The Asian citrus psyllid, Diaphorina citri Kuwayama, Hemiptera: Psyllidae, is a phloem feeding insect native to Asia and the Far East with a host range of only Citrus spp. and its near Rutaceae relatives (Halbert \& Núñez, 2004). Diaphorina citri causes little direct feeding damage, but it vectors the phloem limited bacterial citrus pathogens, 'Candidatus Liberibacter asiaticus', 'C. L. africanus', and 'C. L. americanus', which cause 'citrus greening disease' or Huanglongbing (HLB), a disease which is considered one of the most damaging to citrus (Capoor et al., 1967; Martinez \& Wallace, 1967; Teixeira et al., 2005). The impact of this disease on world citrus production and concern over its continued spread have lead to research on the vector's plant host range, interactions with parasitoids and host-vector-pathogen interactions (Bové, 2006; Halbert \& Manjunath, 2004; Hall et al., 2008). Despite these endeavors, there is virtually no information available regarding $D$. citri genetic diversity and the implications this may hold for these and other studies.

The Asian citrus psyllid's current distribution extends from the Arabian Peninsula (Saudi Arabia and Yemen) and from Afghanistan through to the Indian Subcontinent, Southeast Asia and the Ryukyu Archipelago and Kyushu in Japan, Taiwan, Hong Kong and the coastal provinces of Guangxi, Guangdong, Fujian and Zhejiang in China, the Philippine Islands and through the Indonesian archipelago to northeastern Papua New Guinea; in the Pacific Islands of Hawaii and Guam; the continental USA (Alabama, California, Florida, Georgia, Louisiana, Mississippi, South Carolina and Texas), as well as the Caribbean (Bahamas, Cayman Islands, Cuba, Jamaica, Dominican Republic, Guadeloupe and the Commonwealth of Puerto Rico), Central (Honduras and Mexico) and South America (Argentina, Brazil, Paraguay, Uruguay and Venezuela) and the Indian Ocean islands of Mauritius and Réunion (Costa Lima, 1942; French et al., 2001; Halbert \& Manjunath, 2004; Halbert \& Núñez, 2004; Mead, 1977; Pluke et al., 2008; Tsai et al., 2000). Because of the lack of global phylogenetics for this species, hypotheses describing its origin include either southeastern Asia or southwestern Asia (India/Pakistan) (Mead, 1977). Anthropogenic spread via the pathway of infested plant material has been the principal means by which this pest has spread. This was responsible for the New World invasions that have seen its distribution expand to include countries in North, Central and South America and the Caribbean (Núñez, 2004). Diaphorina citri was first reported from the continental USA (Florida) in 1998 (Bové, 2006) and now occurs from Florida to California.

Understanding the genetic diversity underlying an invasive pest is a key element that supports the development of effective management strategies (Rosen, 1978; Schauff et al., 1998). Complicating the analysis of genetic diversity among world populations of many invasive insects is that many contain a cryptically diverse collection of populations that cannot be easily categorized by morphological characteristics (Scheffer, 2000; Clarke et al., 2005). Diversity can be represented as distinct biotypes and may extend to reproductive isolation, suggesting the existence of multiple cryptic species (Bickford et al., 2007; De Barro et al., 2011). The emergence of molecular systematic approaches has allowed the more precise and rapid characterization of diversity among populations of invasive species beyond what can be ascertained from morphological evaluations. This information can be used to identify the geographic origin of the invaders, if not directly, then at least from an evolutionary perspective (Xavier et al., 2009; De Barro \& Ahmed, 2011). Such knowledge is invaluable when looking for effective biological control agents, and understanding basic biology and ecology.

The purpose of this study was to use mitochondrial cytochrome oxidase I (mtCO1) to assess the genetic relationships between different collections of $D$. citri from around the world. The questions we set out to answer were: (i) Can mtCOI haplotype analysis provide an insight into phylogeographic relationships of Old World D. citri populations? If so, (ii) is there population structure that can be used to monitor global movement of specific genetic types? And, (iii) is there evidence of cryptic species based on relative genetic relationships of individuals from the different collections?

\section{Methods}

\section{Collection of global D. citri collections and outgroup selection}

Individuals were collected from Bali, Brazil, China, USA (Florida and Texas), Guadeloupe, India, Java, Mauritius Island, Mexico, Pakistan, Puerto Rico, Réunion Island, Saudia Arabia, Taiwan, Texas-USA, Thailand and Vietnam (table 1). All material was stored in $70 \%$ ethanol until DNA was extracted. In most cases, multiple individuals were collected in each location. Truncated sequences (sequences less than 550 base pairs) were deleted to leave a final aligned data set of 212 individual sequences. These sequences were then screened using a similarity matrix, and eight unique haplotypes were identified. An outgroup mtCOI sequence was from Pachypsylla venusta, the hackberry petiole gall psyllid (NC_006157). This was chosen because it was the closest psyllid relative for which the entire $612 \mathrm{bp}$ mtCOI sequence was available and was used to aid in alignment.

\section{Identification of novel COI primers specific for $\mathrm{D}$. citri}

Amplification of mtCOI was not successful using the universal primers C1-J-2195 and TL2-N-3014 (Simon et al., 1994). New mtCOI primers for D. citri were designed from an EST library generated at the USDA (Hunter et al., 2008) and available in GenBank (http://www.ncbi.nlm.nih.gov/). The primers were: DCITRI COI-L 5'- AGG AGG TGG AGA CCC AAT CT and DCITRI COI-R 5'- TCA ATT GGG GGA GAG TTT TG. These amplify an 821 base pair fragment of the mtCOI coding region.

\section{DNA extraction, amplification and sequencing}

Total DNA was extracted using Cartagen's (http://www. cartagen.com) rapid homogenization kit for plant leaf DNA amplification (catalog number 20700-500, lot number 08180400134). The $30 \mu \mathrm{l} \mathrm{PCR}$ reactions were heated at $94^{\circ} \mathrm{C}$ for two minutes followed by 35 cycles of $30 \mathrm{~s}$ at $94^{\circ} \mathrm{C}$ denaturation, $30 \mathrm{~s}$ at $53^{\circ} \mathrm{C}$ annealing, $1 \mathrm{~min}$ at $72^{\circ} \mathrm{C}$ extension and a final extension of $72^{\circ} \mathrm{C}$ for $10 \mathrm{~min}$ in a MJ Research PTC200 Peltier thermal cycler. The PCR reactions were composed of $27 \mu$ Platinum PCR SuperMix (Invitrogen, catalog number 11306-016), $1 \mu \mathrm{l}$ forward primer (10 $\rho \mathrm{mol}), 1 \mu \mathrm{l}$ reverse primer (10 $\mathrm{\rho mol})$, and $1 \mu \mathrm{l}$ DNA template. Prior to sequencing, the amplified products were cleaned using the montage PCR filter units from Millipore (catalog number UFC7PCR50). All sequencing was performed using the amplification primers and BigDye® Terminator Cycle Sequencing Kits. Sequence 
Table 1. Accession numbers for each of the 212 sequences from 52 populations of Diaphorina citri used to generate fig. 1.

Location

USA, Florida
Palm Beach, Co. (16)

Brevard, Co. (10)

Miami-Dade, Co. (4)

Broward, Co. (2)

Genebank Code

psy1-1-dcitrico1

psy1-2-dcitrico1

psy1-3-dcitrico1

psy1-4-dcitrico1

psy1-5-dcitrico1

psy9-1-dcitrico1

psy9-2-dcitrico1

psy9-3-dcitrico1

psy9-4-dcitrico1

psy9-5-dcitrico1

psy10-1-dcitrico1

psy10-2-dcitrico1

psy10-3-dcitrico1

psy10-4-dcitrico1

psy10-5-dcitrico1

psy11-1-dcitrico1

psy11-2-dcitrico1

psy11-3-dcitrico1

psy11-4-dcitrico1

psy11-5-dcitrico1

psy18-1-dcitrico1

psy18-2-dcitrico1

psy18-3-dcitrico1

psy18-4-dcitrico1

psy18-5-dcitrico1

psy30-1-dcitrico1

psy30-3-dcitrico1

psy21-1-dcitrico1

psy21-2-dcitrico1

psy21-3-dcitrico1

psy21-4-dcitrico1

psy21-5-dcitrico1

psy2-1-dcitrico1

psy2-2-dcitrico1

psy2-3-dcitrico1

psy2-4-dcitrico1

psy2-5-dcitrico1

psy4-1-dcitrico1

psy4-2-dcitrico1

psy4-3-dcitrico1

psy4-4-dcitrico1

psy4-5-dcitrico1

psy16-1-dcitrico1

psy16-5-dcitrico1

psy20-1-dcitrico1

psy20-2-dcitrico1

psy20-4-dcitrico1

psy20-5-dcitrico1

psy13-1-dcitrico1

psy13-2-dcitrico1

psy13-3-dcitrico1

psy13-4-dcitrico1

psy13-5-dcitrico1

psy19-1-dcitrico1

psy19-2-dcitrico1

psy19-3-dcitrico1

psy19-4-dcitrico1

psy19-5-dcitrico1

psy23-1-dcitrico1

psy23-3-dcitrico1

psy23-4-dcitrico1

psy23-5-dcitrico1

psy39-2-dcitrico1

psy39-5-dcitrico1
Accession Number

FJ190167

FJ190168

FJ190169

FJ190170

FJ190171

FJ190192

FJ190193

FJ190194

FJ190195

FJ190196

FJ190197

FJ190198

FJ190199

FJ190200

FJ190201

FJ190202

FJ190203

FJ190204

FJ190205

FJ190206

FJ190232

FJ190233

FJ190234

FJ190235

FJ190236

FJ190277

FJ190278

FJ190246

FJ190247

FJ190248

FJ190249

FJ190250

FJ190172

FJ190173

FJ190174

FJ190175

FJ190176

FJ190182

FJ190183

FJ190184

FJ190185

FJ190186

FJ190226

FJ190227

FJ190242

FJ190243

FJ190244

FJ190245

FJ190211

FJ190212

FJ190213

FJ190214

FJ190215

FJ190237

FJ190238

FJ190239

FJ190240

FJ190241

FJ190256

FJ190257

FJ190258

FJ190259

FJ190310

FJ190311
Haplotype Assignment*

Dcit-1

Dcit-1

Dcit-1

Dcit-1

Dcit-1

Dcit-1

Dcit-1

Dcit-1

Dcit-1

Dcit-1

Dcit-1

Dcit-1

Dcit-1

Dcit-1

Dcit-1

Dcit-1

Dcit-1

Dcit-1

Dcit-1

Dcit-1

Dcit-1

Dcit-1

Dcit-1

Dcit-1

Dcit-1

Dcit-1

Dcit-1

Dcit-1

Dcit-1

Dcit-7

Dcit-1

Dcit-1

Dcit-1

Dcit-1

Dcit-1

Dcit-1

Dcit-1

Dcit-1

Dcit-1

Dcit-1

Dcit-1

Dcit-1

Dcit-1

Dcit-1

Dcit-1

Dcit-1

Dcit-1

Dcit-1

Dcit-1

Dcit-1

Dcit-1

Dcit-1

Dcit-1

Dcit-1

Dcit-1

Dcit-1

Dcit-1

Dcit-1

Dcit-1

Dcit-1

Dcit-1

Dcit-1

Dcit-1

Dcit-1 
Table 1. (Cont.)

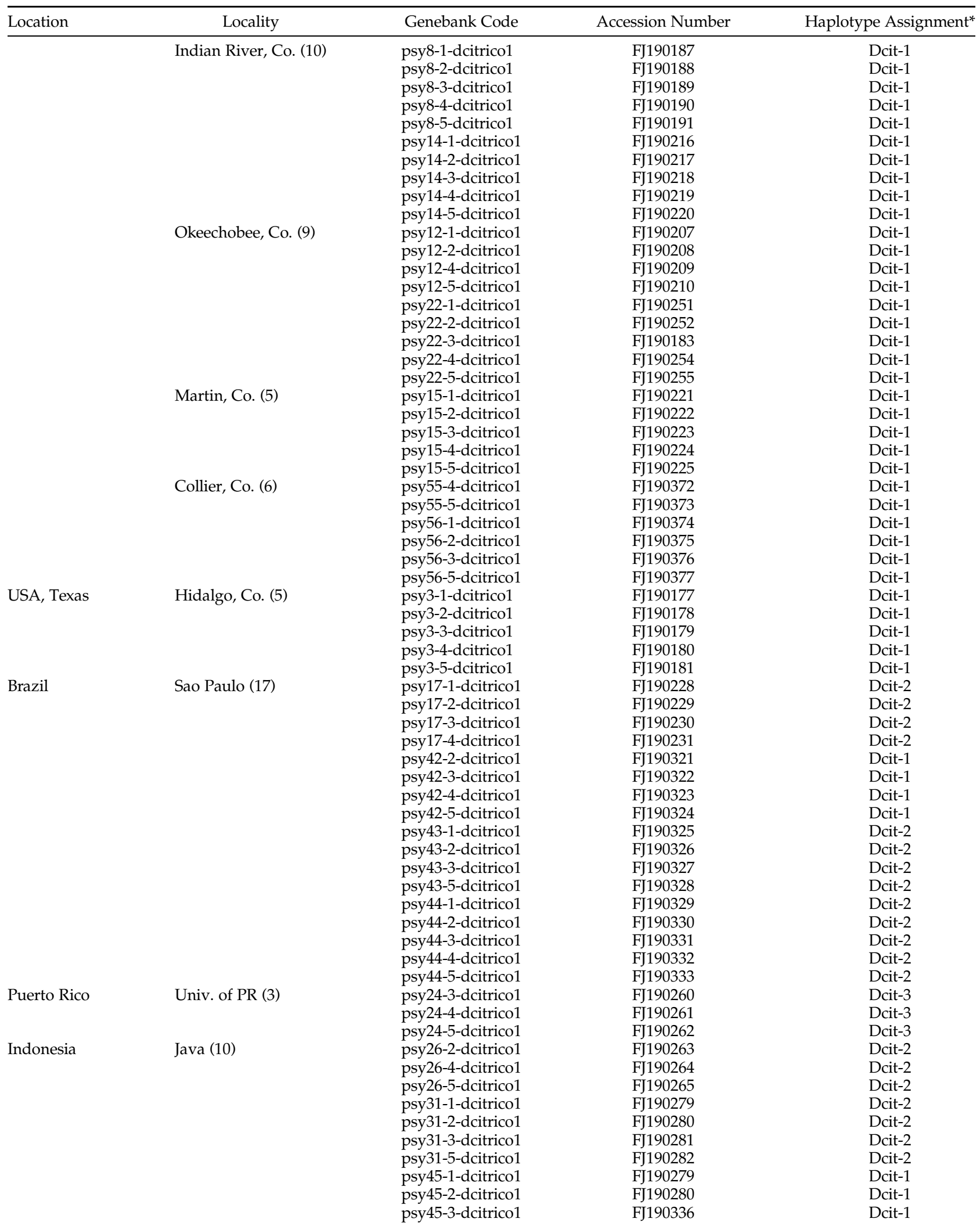


Table 1. (Cont.)

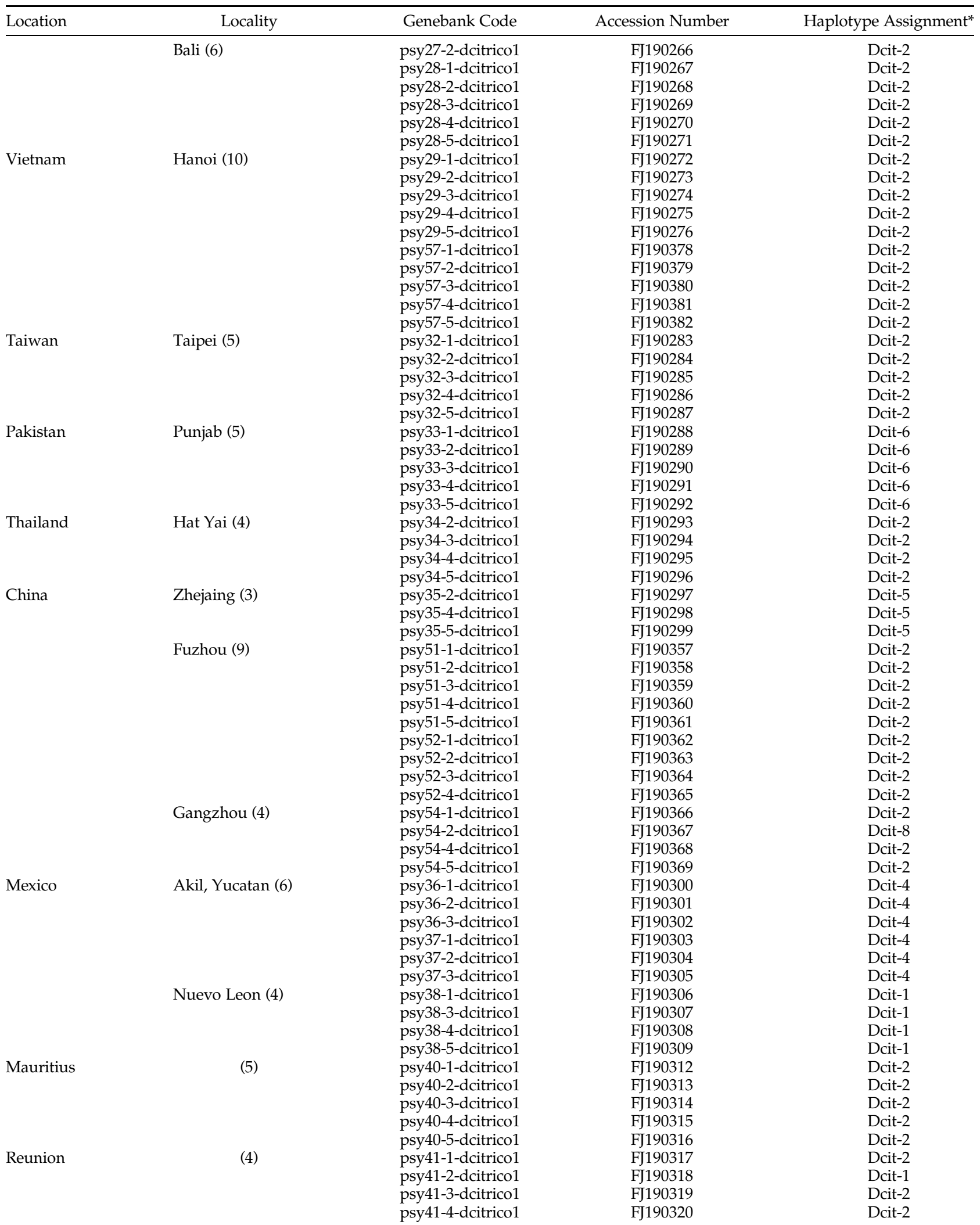


Table 1. (Cont.)

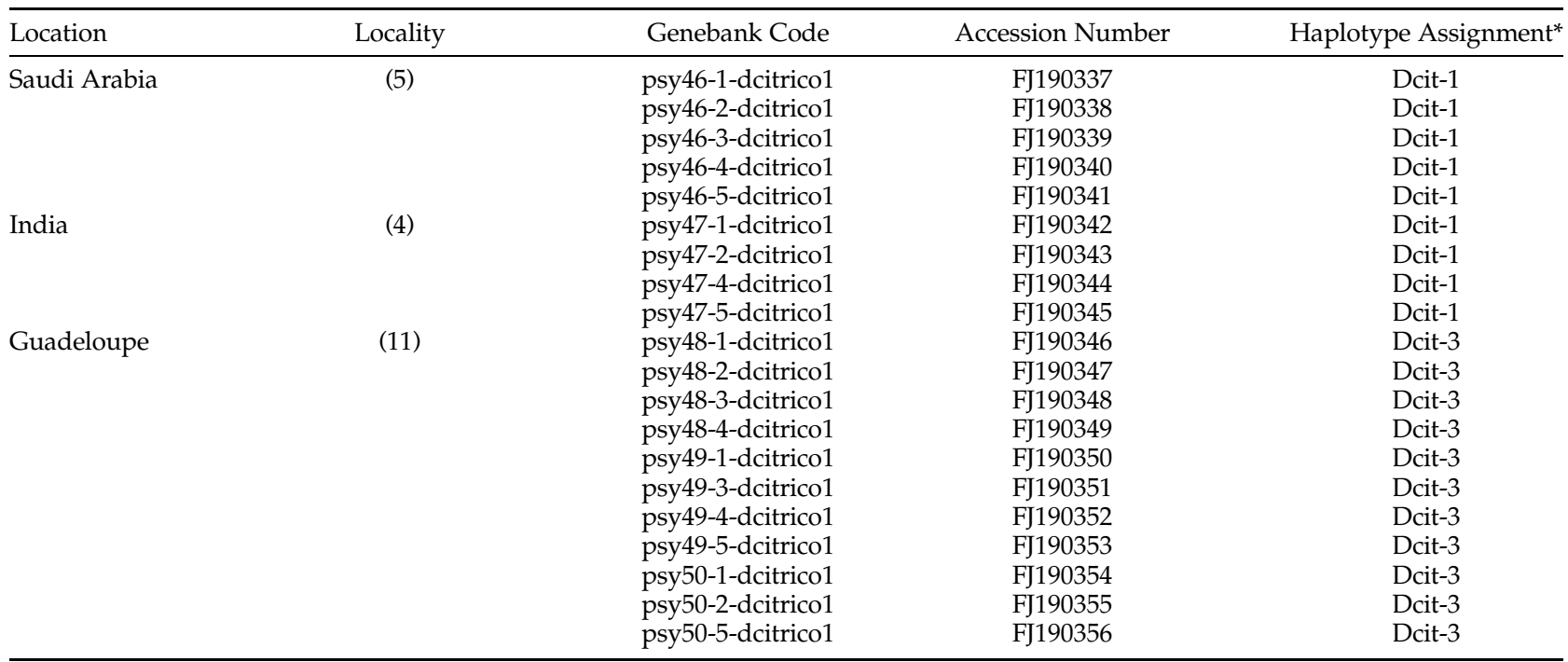

* Haplotype assignments are as defined in table 2.

analysis was conducted on an Applied Biosystems $3730 \times 1$ DNA Analyzer. Sequence fragments were assembled with Sequencher ${ }^{\circledR}$ version 4.2 (Gene Codes Corporation, 2004) and aligned using ClustalX (Thompson et al., 1997). Minor alignment issues were corrected using Se-Al (Rambaut, 2000). Sequences generated at the United States Horticultural Research Laboratory (USHRL) were deposited in GenBank (table 1), and voucher specimens are deposited in the USHRL collection in Fort Pierce, Florida.

\section{Haplotype network construction}

A haplotype network was constructed using the statistical parsimony program TCS (Clement et al., 2000). TCS estimates phylogenetics networks from DNA sequences or nucleotide distances using the statistical parsimony algorithm which estimates the $95 \%$ parsimony limits and outgroup weights (Templeton et al., 1992). Computation was performed using an alignment of each of the eight haplotypes produced in ClustalX. The program was used to construct a statistical parsimony cladogram from parsimonious connections calculated at $P_{\mathrm{j}} \geq 0.95$ and a matrix of absolute pairwise differences was calculated. Haplotype frequencies were not used to calculate outgroup probabilities, as there was minimal sharing of haplotypes among locations and our sampling effort was not uniform (e.g. there was more sampling within Florida than elsewhere).

\section{Results and discussion}

\section{Identification of $\mathrm{D}$. citri mtCOI haplotypes}

Alignment of the mtCOI sequences showed the presence of eight polymorphic sites within the 612 bps. Four of the substitutions corresponded to synonymous sites and four to non-synonymous (amino-acid altering) sites (table 2). Six of the eight polymorphisms were the result of transitions while two were from transversions. The eight haplotypes were highly similar with shared identities $>99 \%$ (table 2 ). Two of these haplotypes (Dcit-1 and Dcit-2) were the most frequent and represented $87 \%$ of the sequences (table 3 ). Of the remaining six haplotypes, two (Dcit-7 and Dcit-8) were rare variants found among populations predominated by Dcit- 1 or Dcit-2. The other four haplotypes (Dcit-3, Dcit-4, Dcit-5 and Dcit-6), without the benefit of larger sample sizes, appear to be fixed in their respective populations.

The rare haplotypes Dcit-7 and Dcit- 8 were each recovered from a single individual in Florida and China, respectively. Moreover, each of these rare variants differed from all other sequences by a single non-synonymous (amino acid altering) substitution at an otherwise invariant site. Inspection of sequence chromatograms shows clean sequence reads for both variants, indicating that these were not related to sequence read errors.

\section{Global relationships of $\mathrm{D}$. citri}

Due to the minimal sequence diversity in this intraspecific haplotype comparison, and the resulting poor support for the phylogenetic inference using standard tree construction methods (data not shown), it was determined that a haplotype network analysis would be the most appropriate way to consider the relationship between haplotypes (Hart \& Sunday, 2007; Chen et al., 2010; De Barro \& Ahmed, 2011). The analysis using TCS is graphically represented in fig. 1.

By considering the two most frequently encountered haplotypes and their singleton derivatives as separate 'groups', Dcit-1 groups with Dcit-4, Dcit-6 and Dcit-7 to form what we refer to as the SWA group. Dcit-1 was the most frequently encountered haplotype in this group. The other haplotype group was composed of Dcit-2 and Dcit-8 and represents the SEA group. Placement of Dcit-3 (all Caribbean collections) and Dcit-5 (a single Chinese collection) was ambiguous, possibly because of the small numbers collected from those areas and because of the greater number 
Table 2. Unique haplotypes and polymorphism locations observed from the alignment of the 212 Diaphorina citri mtCOI sequences.

\begin{tabular}{|c|c|c|c|c|c|c|c|c|}
\hline Haplotype & \multicolumn{8}{|c|}{ Base location relative to start of the FJ190167 accession } \\
\hline Dcit-1 & G & A & G & G & G & A & A & A \\
\hline Dcit-2 & A & A & G & G & G & A & A & G \\
\hline Dcit-4 & G & A & G & G & G & C & A & A \\
\hline Dcit-5 & A & A & G & G & G & $\mathrm{C}$ & A & A \\
\hline Dcit-6 & G & A & G & A & G & A & A & A \\
\hline Sub. Type* & Ns & $S$ & Ns & $S$ & Ns & Ns & S & S \\
\hline
\end{tabular}

* Substitution type is indicated as (S) synonymous or (Ns) nonsynonymous.

Table 3. Geographic distribution and abundance of Diaphorina citri haplotypes.

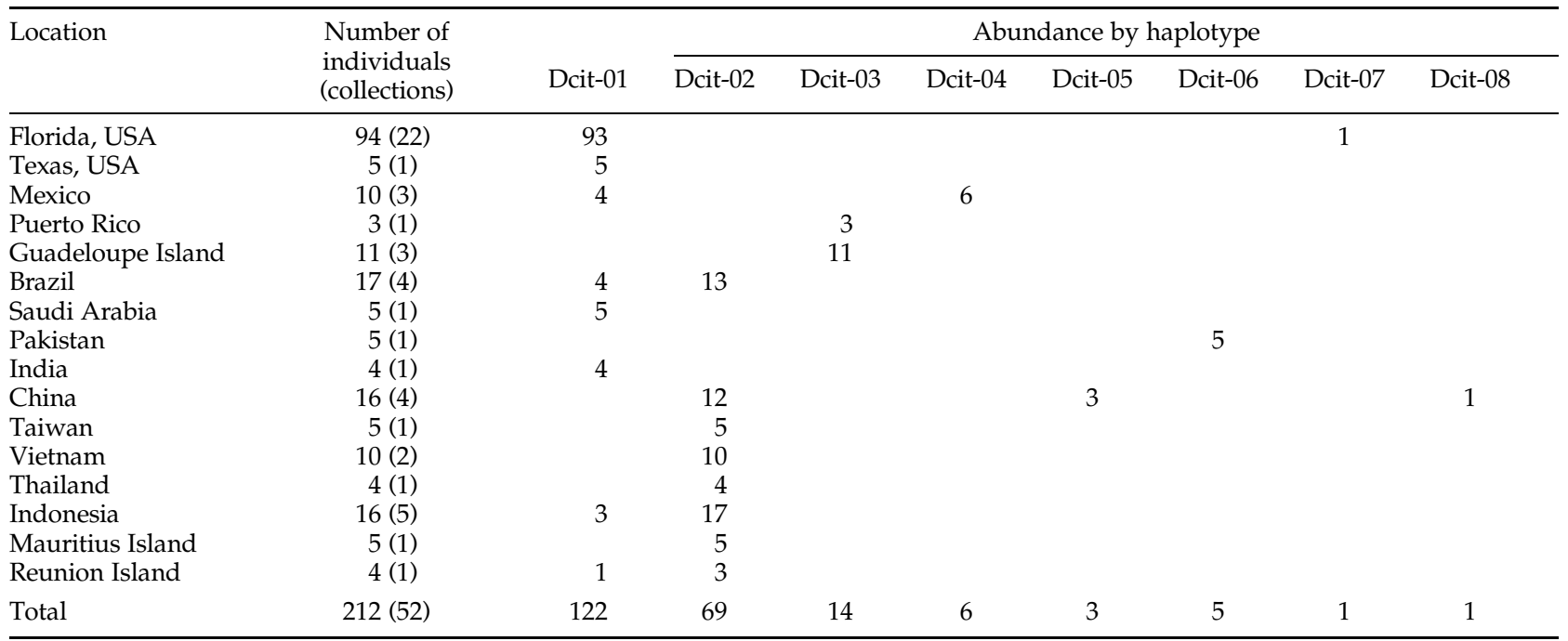

of nucleotide substitutions in relation to the most common sequences.

This network analysis shows a diverged haplotype, Dcit-3, distributed in the Caribbean yet absent from all other samples (fig. 1). This result was surprising since the Caribbean was thought to be the source of $D$. citri that entered Florida (Halbert \& Núñez, 2004). Since Dcit-3 is not found in Florida, either the Florida $D$. citri have come from some location other than the Caribbean or there is greater diversity in the Caribbean than we observed in the four collections (Psy-24, $-48,-49,-50)$ and 13 individuals obtained from Puerto Rico and Guadaloupe (table 1). The relatively distant relationship between the Florida and Caribbean haplotypes (three substitutions, see fig. 1) indicate that the invasion of Florida did not come from the established Caribbean (Guadeloupe and Puerto Rico) populations, but more sampling is needed to verify these findings. Further, because D. citri is hypothesized to have entered the Caribbean as recently as the 1990s (Hall, 2008) and the Caribbean samples have a mtCOI genotype that was not found anywhere else in the old world, we are left to draw the conclusion that there is more worldwide diversity than what was captured in our sampling.

Within the Old World, few haplotypes predominate. However, the distribution of these haplotypes suggests a phylogeographic break. Dcit- 2 occurs in $>90 \%$ of all the Southeast Asia individuals and $75 \%$ of all Chinese samples. Despite its common occurrence in SE Asia and China, it appears to be absent from the Middle East and the Indian subcontinent. Conversely, Dcit-1 and Dcit-6, just one synonymous mutation away, are the only haplotypes observed in both the Middle East and Indian subcontinent. Considering all the haplotypes present in Old World collections, Dcit-1 and Dcit-6 displayed a southwestern Asia (SWA) bias and Dcit-2, -5 and -8 a southeastern Asia bias.

In the New World, where D. citri was introduced within the last 25 years (Halbert \& Núñez, 2004), a geographical bias to haplotype distribution was also observed. With the exception of one individual carrying haplotype Dcit-7, all 23 USA collections (99 individuals) contained Dcit-1. The individual carrying Dcit-7, which differs by a single nonsynonymous substitution, was collected from St Lucie County, Florida alongside Dcit-1. In the four Brazilian collections, both Dcit-1 and Dcit-2 haplotypes were observed, but not in the same collections. In Mexico, three collections were analyzed, one from northern Mexico near the Texas, USA border and the other two from the Yucatan Peninsula. The collection close to Texas contained the same haplotype found in Texas (Dcit-1), but the Yucatan Peninsula collections 


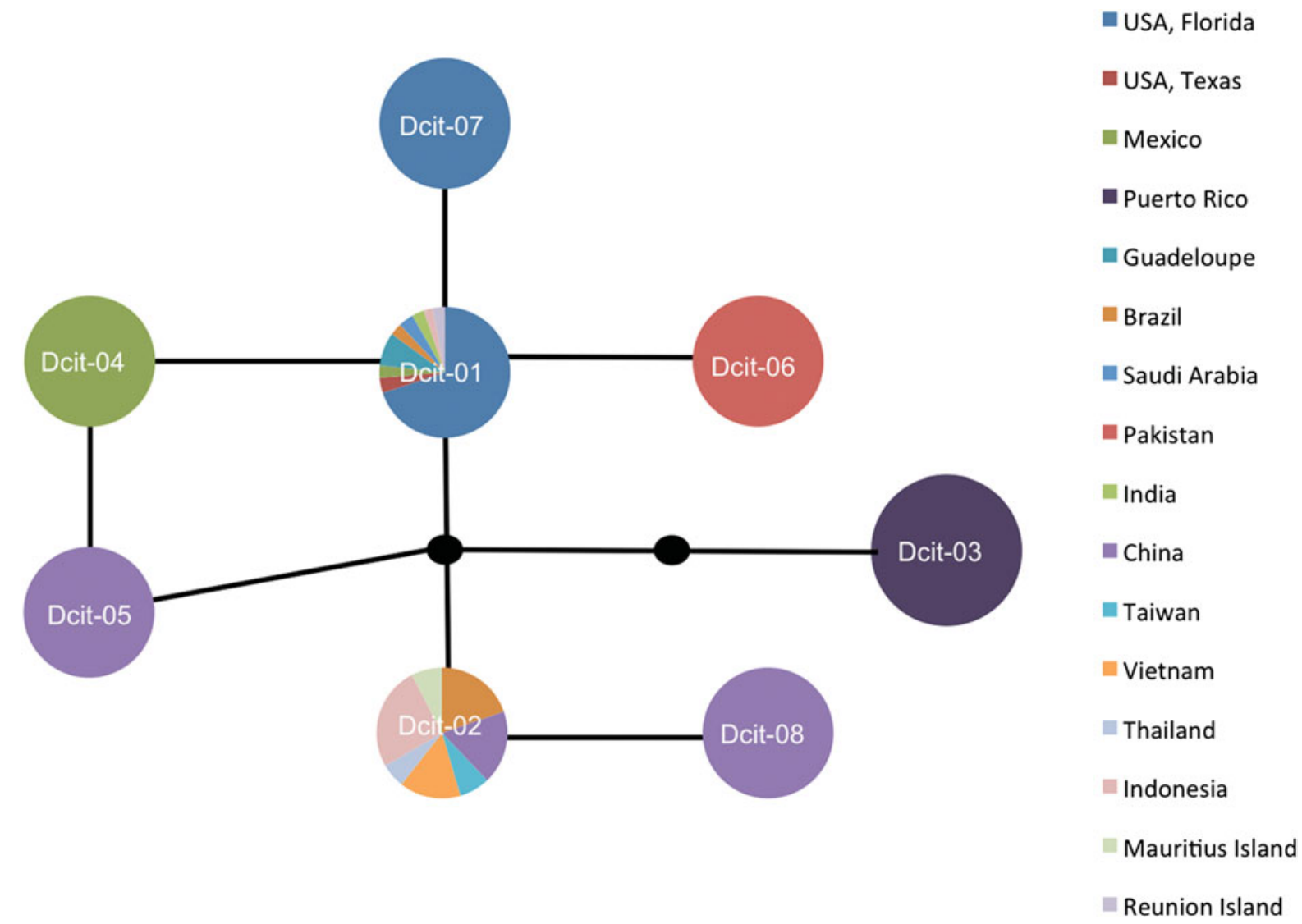

Fig. 1. Haplotype network generated with statistical parsimony analysis of $D$. citri mtCOI DNA sequence. Multicolored markers indicate the presence and identity of multiple haplotypes found within a region. The block dots represent hypothetical haplotypes. See table 3 to evaluate haplotype frequencies.

were fixed for a unique haplotype Dcit-4, which differed from Dcit- 1 by a single nucleotide. Although D. citri is a pest that has spread worldwide, unlike other pests such as the whitefly Bemisia tabaci (Boykin et al., 2007b; Dinsdale et al., 2010), the low level of sequence diversity indicates that it is most likely a single species rather than a species complex.

A major aim of this study was to show how D. citri in Florida are related to $D$. citri elsewhere. We found that the Florida D. citri were most closely related to those from Mexico, Pakistan, Brazil, Texas, Saudi Arabia, India, Indonesia and Réunion Island, and includes the SWA sequences. New World populations show three distinct separations based on phylogeographic interpretation of the haplotype network (fig. 1). North American continental populations (USA: Florida and Texas; and Mexico) belong to the SWA group, whereas individuals from locations in South America were either SWA or SEA in origin; SWA and SEA did not co-occur in any of the collections, suggesting two separate introductions. The only case where a collection from a single location contained individuals from both SWA and SEA was in the Indian Ocean island of Réunion. It is interesting to consider here whether there is some factor that limits the capacity of these two groups to co-occur. The only other New World locations sampled were the two Caribbean islands of Puerto Rico and Guadeloupe, where both contained the same haplotype Dcit-3.
Geographic origins of D. citri

Network-based genealogies can offer insight into ancestral sequences, as these sequences are expected to be common, widely distributed and highly connected (Chen et al., 2010). While these predictions hold in theory, application is often difficult. Insufficient or non-uniform sampling schemes can bias the frequencies of observed haplotypes. Anthropogenic activity can alter geographical distributions at a scale and rate well beyond the ability of genetic systems to equilibrate. In our study, $>60 \%$ of our samples are from the New World where $D$. citri is invasive. Using frequency of occurrence or geographic distribution as a metric for predicting ancestry would bias predictions by frequency of invasion and invasion success.

While both haplotype frequency and geographical distribution are likely not reflective of equilibrium evolutionary processes, patterns of haplotype connectivity may be more robust. Using this criterion, the mitochondrial haplotype network for $D$. citri suggests a basal and thus ancestral position for Dcit-1 (fig. 1). Even a conservative analysis, excluding all New World haplotypes that were singleton branches from the main Dcit- 1 and Dcit- 2 groups leaving only old world haplotypes, predicts Dcit-1 as ancestral based on connectivity.

Although early work suggested a far eastern Asia (Asia region to the east of India) origin of D. citri (Mead, 1977), more 
recent reconstructions based on plant host origins and historical information suggest a southwestern Asia origin, i.e. India (Hall, 2008). Therefore, ancestral placement of the SWA group supports the more contemporary view of $D$. citri evolution. However, because of limited sampling in the Old World, we do not have a clear phylogeographic picture of the complete distribution of the SWA and SEA groups. The phylogeographic interpretations of our data identify two geographical redistributions of $D$. citri. First, some apparent geographical separation between the SWA and SEA groups that requires more intense sampling in the Old World to provide a true characterization of this relationship, and then a more recent radiation of the SWA and SEA groups into the New World most likely within the last 25 years (Halbert \& Núñez, 2004). There is one earlier report of D. citri from Brazil in the early 1940s (Costa Lima, 1942); however, no one can substantiate this record, and it is certain that established populations were not reported until much more recently.

\section{Conclusion}

Our data indicate that with respect to the mCOI haplotypes and within the limits of our global sampling, there is very little genetic diversity among the populations worldwide. Despite this limited diversity, enough information was gained to partially answer the three questions on which this research was based.

(i) Can mtCOI haplotype analysis provide an insight into phylogeographic relationships of Old World D. citri populations? Limited sampling became a factor in this interpretation; however, two mtCOI haplotypes predominate, Dcit-1 and Dcit-2. These differed from each other by just two nucleotides and formed the basis of Dcit-1 group individuals (Dcit -1,-4, -6 and -7) and Dcit-2 group individuals (Dcit-2 and -8 ), as defined by those individuals whose mtCOI sequence diverges from the most common sequence (either Dcit-1 or Dcit-2) by only one nucleotide. Distribution of these two haplotype groups displayed some apparent Old World geographical bias. The Dcit-1 group was more abundant in SWA samples, and the Dcit-2 group was more abundant in SEA samples. Clearly, more sampling was done in SEA (Indonesia, Vietnam, Taiwan, Thailand and China) with 12 different collections, than in SWA (Pakistan, Saudia Arabia and India) with only three collections. However, if collections from Mauritius and Reunion are excluded as anthropogenic introductions because they are not considered a center of $D$. citri diversity and are isolated islands where both Dcit- 1 and-2 are present, 11 of the 12 SEA samples contained individuals belonging to the Dcit-2 group, while all SWA samples contained only Dcit-1 group individuals. Based on these results, there is an appearance of geographically distinct populations; however, due to the limited sequence divergence between the observed groups, more in-depth sampling is needed for this to be verified. The authors suggest that further sampling from these Middle East and Asian countries needs to be conducted to better survey diversity and also utilize the other genetic markers such as microsatellites (Boykin et al., 2007a).

(ii) Is there population structure that can be used to monitor global movement of specific genetic types? Analysis of the New World collections showed that invasions into North America came from the SWA group only, whereas those involving South America came from both the SWA and SEA groups. There was extensive sampling in the USA
(22 collections within Florida) and only minimal sampling in South America (four collections), so it is unlikely that SEA populations were missed in the USA. Despite this observed difference in haplotype distribution in the New World, our limited Old World sampling and the small amount of global mtCOI sequence variation precludes the ability to provide a concise determination of origin. However, knowledge from this research may be useful in searching for effective biological control agents and may help explain differences in effectiveness of Tamarixia radiata, a parasitoid introduced in the New World to control invasive populations of D. citri (Hoy \& Nguyen, 2001; Hoy et al., 2004; Michaund, 2004; Pluke et al., 2008; Barr et al., 2009). Although, one needs to be cautious here, as ecological factors may be as or more important than genetic variability within the parasitoid and should not be overlooked.

(iii) Is there evidence of cryptic species based on relative genetic relationships of collections? All individuals were closely related, and there is no evidence for complex cryptic species structure within these populations. This may be expected as genetic variation is expected to increase with time since divergence (globalization) and increased host variability (local adaptation). D. citri has a very limited host range (only within the Rutaceae) and has only recently (within the last 15 to 25 years) spread to the New World.

\section{Acknowledgements}

The authors would like to thank Ankush Zitsi, Chris Knox, Paula Hall, Kathy Moulton, Matthew Hentz and John Prokop for laboratory assistance of the $D$. citri collections at the USHRL. Diana Percy provided valuable discussions regarding sequencing of the COI region. W. Evan Braswell provided useful comments to the manuscript, table 3 and fig. 1 . We thank Y. S. Ahlawat, Virendra Baranwal, Shahid Nadeem Chohan, Shu-Sheng Liu, Baoli Qui, Ratana Sdoodee and Siti Subandiyah for providing us with samples.

\section{References}

Barr, N.B., Hall, D.G., Weathersbee III, A.A., Nguyen, R., Stansly, P., Qureshi, J.A. \& Flores, D. (2009) Comparison of laboratory colonies and field populations of Tamarixia radiata, an ectoparasitoid of the Asian citrus psyllid, using internal transcribed spacer and cytochrome oxidase subunit I DNA sequences. Journal of Economic Entomology 102, 2325-2332.

Bickford, D., Lohman, D.J., Sodhi, N.S., Ng, P.K., Meier, R., Winker, K., Ingram, K.K. \& Das, I. (2007) Cryptic species as a window on diversity and conservation. Trends in Ecology and Evolution 22, 148-155.

Bové, J. (2006) Huanglongbing: a destructive, newly-emerging, century-old disease of citrus. Journal of Plant Pathology 88, 7-37.

Boykin, L.M., Bagnall, R.A., Frohlich, D.R., Hall, D.G., Hunter, W.B., Katsar, C.S., McKenzie, C.L., Rosell, R.C. \& Shatters, R.G. (2007a) Twelve polymorphic microsatellite loci from the Asian citrus psyllid, Diaphorina citri Kuwayama, the vector for citrus greening disease, huanglongbing. Molecular Ecology Notes 7, 1202-1204.

Boykin, L.M., Shatters, R.G. Jr, Rosell, R.C., McKenzie, C.L., Bagnall, R.A., De Barro, P. \& Frohlich, D.R. (2007b) Global relationships of Bemisia tabaci (Hemiptera: Aleyrodidae) revealed using Bayesian analysis of mitochondrial COI 
DNA sequences. Molecular Phylogenetics and Evolution 44, 1306-1319.

Capoor, S., Rao, D.G. \& Viswanath, S.M. (1967) Diaphorina citri Kuway., a vector of greening disease of citrus in India. Indian Journal of Agricultural Science 37, 572-576.

Chen, H., Strand, M., Norenburg, J.L., Sun, S., Kajihara, H., Chernyshev, A.V., Maslakova, S.A. \& Sundberg, P. (2010) Statistical parsimony networks and species assemblages in Cephalotrichid nemerteans (Nemertea). PLoS One 5, e12885.

Clarke, A.R., Armstrong, K.F., Carmichael, A.E., Milne, J.R., Raghu, S., Roderick, G.K. \& Yeates, D.K. (2005) Invasive phytophagous pests arising through a recent tropical evolutionary radiation: the Bactrocera dorsalis complex of fruit flies. Annual Reveiw of Entomology 50, 293-319.

Clement, M., Posada, D. \& Crandall, K.A. (2000) TCS: a computer program to estimate gene genealogies. Molecular Ecology 9, 1657-1659.

Costa Lima, A. (1942) Homopteros. Insetos do Brazil 3, 1-327.

De Barro, P. \& Ahmed, M. (2011) Genetic Networking of the Bemisia tabaci Cryptic Species Complex Reveals Pattern of Biological Invasions. PLoS Biol 6, e25579.

De Barro, P.J., Liu, S.S., Boykin, L.M. \& Dinsdale, A.B. (2011) Bemisia tabaci: A Statement of Species Status. Annual Reveiw of Entomology 56, 1-19.

Dinsdale, A., Cook, L., Riginos, C., Buckley, Y.M. \& De Barro, P. (2010) Refined global analysis of Bemisia tabaci (Gennadius) (Hemiptera: Sternorrhyncha: Aleyroidea) mitochondrial $\mathrm{CO} 1$ to identify species level genetic boundries. Annals of the Entomological Society of America 103, 196-208.

French, J.V., Kahlke, C.J. \& De Graca, J.V. (2001) First record of the Asian citrus psylla Diaphorina citri Kuwayama (Homoptera:Psyllidae), in Texas. Subtropical Plant Science 53, 14-15.

Gene Codes Corporation (2004) Sequencher 4.2. Madison, WI, USA, Gene Codes Corporation, Inc.

Halbert, S.E. \& Manjunath, K.L. (2004) Asian citrus psyllids (Sternorrhyncha: Psyllidae) and greening disease of citrus: A literature review and assessment of risk in Florida. Florida Entomologist 87, 330-353.

Halbert, S.E. \& Núñez, C.A. (2004) Distribution of the Asian citrus psyllid, Diaphorina citri Kuwayama (Rhynchota: Psyllidae), in the Caribbean basin. Florida Entomologist 87, 401-402.

Hall, D.G. (2008) Biology, history and world status of Diaphorina citri. pp. 1-11 in Proceedings of the International Workshop on Huanglongbing and Asian Citrus Psyllid, North American Plant Protection Organization, 7-9 May 2008, Hermosillo, Sonora, Mexico.

Hall, D.G., Hentz, M.G. \& Adair, R.C. Jr (2008) Population ecology and phenology of Diaphorina citri (Hemiptera: Psyllidae) in two Florida citrus groves. Environmental Entomology 37, 914-924.

Hart, M.W. \& Sunday, J. (2007) Things fall apart: biological species form unconnected parsimony networks. Biological Letters 3, 509-512.

Hoy, M.A. \& Nguyen, R. (2001) Classical biological control of Asian citrus psylla. Citrus Industry 81, 48-50.

Hoy, M.A., Nguyen, R. \& Jeyaprakash, A. (2004) Classical biological control of Asian citrus psyllid in Florida. Integrated Pest management Florida, University of Florida, available online at http://ipm.ifas.ufl.edu/agriculture/citrus/psyllid. shtml (accessed 13 March 2012).

Hunter, W., Katsar, C.S., Shatters, R.G. Jr, McKenzie, C.L., Weathersbee, A.A. \& Hall, D.G. (2008) Psyllid biology:
Expressed genes in adult Asian citrus psyllids, Diaphorina citri Kuwayama. The Open Entomology Journal 3, 18-29.

Martinez, A. \& Wallace, J. (1967) Citrus leaf-mottle-yellows disease in the Philippines and transmission of the causal virus by a psyllid, Diaphorina citri. Plant Disease Report 51, 692-695.

Michaund, J.P. (2004) Natural mortality of the Asian citrus psyllid (Homoptera: Psyllidae) in central Florida. Biological Control 296, 260-269.

Mead, F.W. (1977) The Asiatic citrus psyllid, Diaphorina citri Kuwayama (Homoptera: Psyllidae). Florida Department of Agriculture Conservation Service, Division of Plant Industry Entomology Circular 180, Florida Division of Plant Industry, available online at http://www.freshfromflorida.com/pi/ enpp/ento/entcirc/ent180.pdf.

Núñez, C. (2004) Distribution of the Asian Citrus Psyllid, Diaphorina citri Kuwayama (Rhynchota: Psyllidae) in the Caribbean basin. Florida Entomologist 87, 401-402.

Pluke, R.W.H., Qureshi, J.A. \& Stansly, P.A. (2008) Citrus flushing patterns, Diaphorina citri (Hemiptera: Psyllidae) populations and parasitism by Tamarixia radiata (Hymenoptera: Eulophidae) in Puerto Rico. Florida Entomologist 91, 36-42.

Rambaut, A. (2000) Se-Al: Sequence Alignment Editor v2.0. Se-Al v2.0a11 carbon edn. Oxford, UK, University of Oxford.

Rosen, D. (1978) The importance of cryptic species and specific identifications as related to biological control. pp. 23-35 in Romberger, J.A. (Ed.) Biosystematics in Agriculture. Montclair, NJ, USA, Allanheld, Osmun \& Co.

Schauff, M.E., LaSalle, J. \& Wijeskara, G.A. (1998) The Genera of Chalcid Parasitoids (Hymenoptera: Chalcidoidea) of Citrus Leafminer Phyllocnistis citrella Stainton (Lepidoptera: Gracillariidae). Journal of Natural History 32, 1001-1056.

Scheffer, S.J. (2000) Molecular evidence of cryptic species within the Liriomyza huidobrensis (Diptera: Agromyzidae). Journal of Economic Entomology 93, 1146-1151.

Simon, C., Frati, F., Beckenbach, A., Crespi, B., Lui, H. \& Flook, P. (1994) Evolution, weighting, and phylogenetic utility of mitochondrial gene sequences and a compilation of conserved polymerase chain reaction "primers". Annals of the Entomological Society of America 87, 651-701.

Teixeira, D.C., Saillard, C., Eveillard, S., Danet, J.L., Inácio da Costa, P., Ayres, A.J. \& Bové, J. (2005) 'Candidatus Liberibacter americanus', associated with citrus huanglongbing (greening disease) in São Paulo State, Brazil. International Journal of Systematic and Evolutionary Microbiology 55, 1857-1862.

Templeton, A.R., Crandall, K.A. \& Sing, C.F. (1992) A cladistic analysis of phenotypic associations with haplotypes inferred from restriction endonuclease mapping and DNA sequence data. III. Cladogram estimation. Genetics 132, 619-633.

Thompson, J.D., Gibson, T.J., Plewniak, F., Jeanmougin, F. \& Higgins, D.G. (1997) The ClustalX windows interface: flexible strategies for multiple sequence alignment aided by quality analysis tools. Nucleic Acids Research 24, 4876-4882.

Tsai, J.H., Wang, J.J. \& Liu, Y.H. (2000) Sampling of Diaphorina citri (Homoptera: Psyllidae) on orange Jasmine in southern Florida. Florida Entomologist 83, 446-459.

Xavier, R., Santos, A.M., Lima, F.P. \& Branco, M. (2009) Invasion or invisibility: using genetic and distributional data to investigate the alien or indigenous status of the Atlantic populations of the peracarid isopod, Stenosoma nadejda (Rezig 1989). Molecular Ecology 18, 3283-3290. 